Кулешова Галина Ивановна (Москва). Советник РААСН, академик МААМ (Московское отделение). Ученый секретарь ФГБУН Отделение научно-исследовательских работ ГИПРОНИИ РАН (117971, Москва, ул. Губкина, д. 3. ОНИР ГИПРОНИИ РАН). Эл. почта: kuleshgal@yandex.ru.

Kuleshova Galina I. (Moscow). Advisor of RAACS, Academician of the Moscow branch of the International Academy of Architecture. Scientific Secretary at the Research Department of Department of research works of the Head Design and Research Institute of the Russian Academy of Sciences (3 Gubkina st, Moscow, 117971. GIPRONII RAN). E-mail: kuleshgal@yandex.ru.

๑ Кулешова Г.И., 2021. Academia. Архитектура и строительство, № 4, стр. 70-79.

\title{
Университет и город. Очерк эволюции связи университетской институции с городской средой. Часть 1. Мировой опыт
}

Г.И.Кулешова, Советник РААСН, ФГБУН ОНИР ГИПРОНИИ РАН

В стране поставлена задача реализации программы строительства межуниверситетских кампусов - важных ресурсов развития как образовательного комплекса, так и городской среды региональной столицы. В статье прослежена эволюция развития университетов, их влияние на города размещения, характеристики университетских кампусов за рубежом. 0свещены вопросы современного состояния университетской инфраструктуры, размещение новых кампусов в составе городских территорий.

Ключевые слова: университетский кампус, городская среда, научно-инновационный комплекс, инновационная экономика, модель нового функционала университетского кампуса.

The University and the City. Essays on Evolution of Connection Between University Institution and Urban Environment: World Practice, Peculiarities, Aims and Tasks of Native Practice

\section{G.I.Kuleshova, Advisor of RAACS, GIPRONII RAS}

The country has set the task of implementing a program for the construction of inter-university campuses - important resources for the development of both the educational complex and the urban environment of the regional capital. The article traces the evolution of the development of universities, their influence on the cities of placement. The issues of the current state of the university infrastructure, proposals for the placement of new campuses as part of the projects of the master plans of cities are highlighted.

Keywords: university campus, urban environment, scientific and innovative complex, innovative economy, model of the new functionality of the university campus.

В начале мая 2021 года состоялась Стратегическая сессия Минобрнауки [1], посвященная созданию в России универ- ситетских кампусов мирового уровня. По существу, на сессии было подтверждено уже известное положение о том, что в инновационной экономике университетам принадлежит ключевая роль в обеспечении инновационного развития, подготовке необходимых ключевых компетенций для достижения технологического рывка.

Цель настоящей статьи - опираясь на существующий исторический опыт, показать существенные тренды в размещении университетских кампусов в структуре городских территорий для обеспечения эффективного функционирования образовательного комплекса города и его роль в повышении качества жизни на территории.

Над внедрением модели межвузовских кампусов в рамках Национального проекта «0бразование», Федерального проекта «Экспорт образования» уже несколько лет работает Госкорпорация ВЭБ [2]. Эта модель предполагает создание и развитие так называемой «мягкой инфраструктуры» нового образовательного пространства, направленной на повышение условий и качества жизни студенчества, доступности сервисных и сервисно-технологических служб как для учащихся, так и для горожан.

Эта тема тесно связана с идеологией [3] преобразования существующих университетов в направлении формирования модели «Университет 4.0» (рис. 1), которая поднималась в работе [4], освещающей проектные примеры градостроительного обеспечения этого процесса в отечественной практике.

Изменение идеологии университетов путём добавления к образованию и исследованиям социальной миссии означает изменение и расширение статуса университета для города и горожан, включение студенчества в процессы модернизации и преобразования социальных, культурных, воспитательных функций в широком смысле слова. Благодаря этому университеты становятся драйверами городских изменений в направлении удовлетворения потребностей креативного сообщества - основных акторов инновационного процес- 
са - учёных, исследователей, инженеров, студенчества [5] (рис. 2). Как показали исследования, в странах с активно развивающейся инновационной экономикой углубляются процессы концентрации и консолидации научно-технического потенциала на территориях, в ответ на которые происходит преобразование, модернизация инфраструктуры и повышение качества градостроительной среды в целях обеспечения комфортных условий жизнедеятельности [6].

Именно университеты в большинстве стран запада выступают системообразующими факторами креативной среды городов. В значимых исследованиях последних десятилетий [7] поднимается тема креативного класса, частью которого, наряду с представителями творческих профессий, являются учёные, научные сотрудники и преподаватели высшей школы, а также студенты высшей школы. Образ жизни представителей креативного класса связан с формированием новой культуры потребления - культуры «инвестиций в себя». Этот образ жизни поддерживается «мягкой инфраструктурой», элементы которой обеспечивают максимальное разнообразие форм социальной, культурной жизни, условий сервисного, рекреационного и культурного обслуживания.

\section{Университетский кампус: краткий обзор развития}

Кампусом, по некоторым данным, впервые назвали территорию Принстонского университета в XVIII веке, в связи с чем расширенное толкование содержания феномена университетского кампуса как такового, как правило, понимается в американо-европейский традиции, когда в пределах одной, иногда изолированной, территории размещаются и учебные корпуса, и общежития, и жильё для преподавателей, и спорт, и социально-культурные учреждения - то есть, вся инфраструктура, обеспечивающая эффективность образовательного процесса. Иногда кампусом также называют обособленную территорию, принадлежащую крупной компании, включающую в свою инфраструктуру, среди прочего, корпоративный университет.

Университетская институция возникла на базе старинных монастырей Европы - Болонская правовая школа в XI веке,

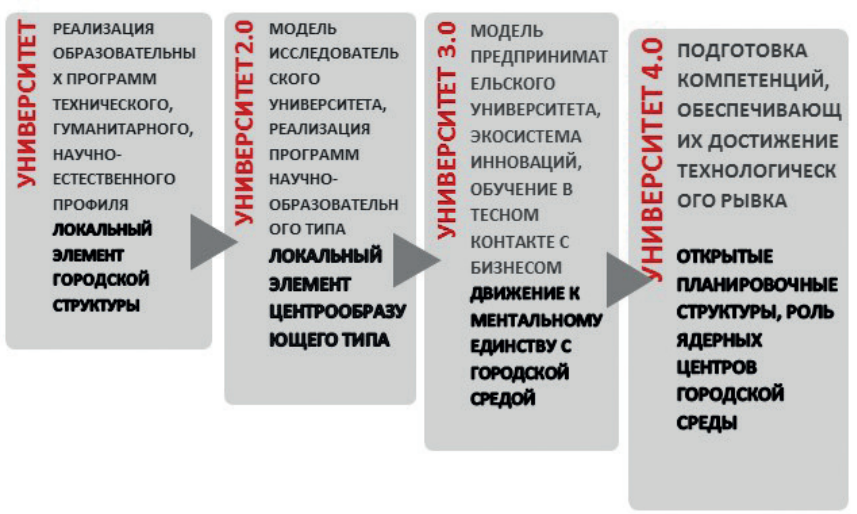

Рис. 1. Эволюция университетской институции и его связь с городской средой. Автор схемы Г.И. Кулешова
Парижский и Оксфордский университеты в XII веке, в начале XIII века - Кембриджский и Лиссабонский, университеты в Саламанке и Коимбре - в конце того же века. В общественной и культурной жизни Европы Средних веков и частично Нового времени университеты играли роль чрезвычайную: они превратились в третью силу вместе с религиозной и светской властью, по крайней мере, в интеллектуальной и духовной сферах [8]. Это сопровождалось полной экономической, правовой и территориальной независимостью университетов, которая и сформировала кампус как пространственно-планировочный феномен. Необходимо сразу обозначить важнейшую характеристику существования и функционирования университетов западного мира: университет - независимый субъект экономики, иногда основной налогоплательщик, определяющий экономическую ситуацию в городе и регионе. Так, в Оксфорде 4,5 млн туристов в год приносят в казну 250 млн фунтов, а инновационная деятельность исследовательских центров Университета и технопарка - 750 млн фунтов [9].

Города в Европе имеют тысячелетний опыт сосуществования с университетами, некоторые из этих городов, как правило, небольших, являют собой полный симбиоз со своим университетом, к примеру - Кембридж, Оксфорд, Лунд, Лейден, - подразумевают и город, и университет. Поскольку университет - важнейший фактор истории, экономики и культуры такого города, в общественных представлениях они практически тождественны. При этом и некоторые университеты новейшей послевоенной истории организовали вокруг себя города - София-Антиполис, Плато Сокле, Сите-Декарт, поднявшись на этой основе до научно-инновационных центров мирового класса - технополисов. На рисунке 3 представлены некоторые из известнейших университетских городов - технополисов Европы [6]. В этих городах кампусом можно назвать всю территорию города, тем более что в большинстве западных университетов количество мест в общежитиях весьма невелико по отношению к обучающимся и распространено проживание студентов в частном сектора на условиях хостинга.

Очевидно, что европейские университетские города, будучи расположены в системе высокоплотного расселения и

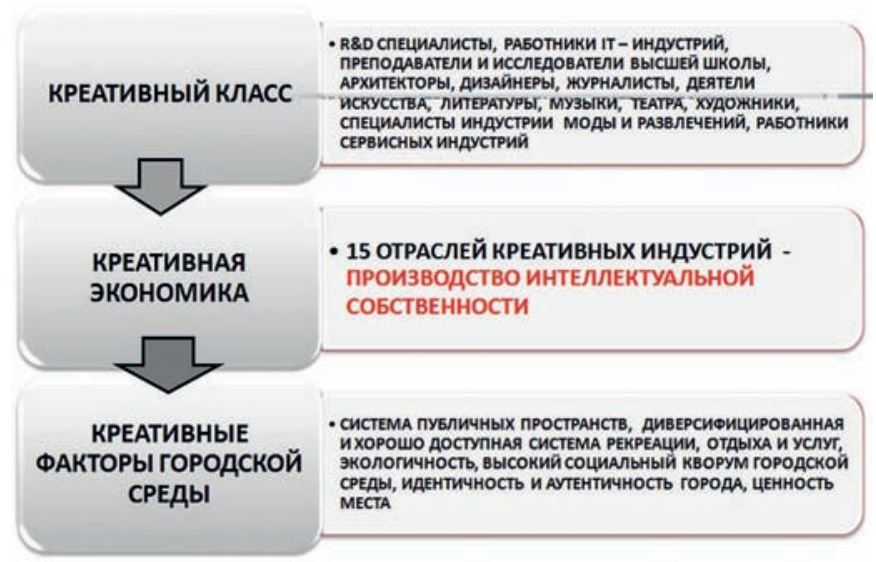

Pис. 2. Схема формирования креативных факторов городской среды и их содержание. Автор схемы Г.И. Кулешова 
имея историко-культурный потенциал европейского и мирового уровня, характеризуются высоким качеством городской среды [10].

С известной полнотой эти вопросы освещены в [6]. Проведенный в монографии анализ имеет значение для продвижения в направлении понимания проблематики формирования градостроительных условий обеспечения эффективного развития как собственно научно-инновационной деятельности, так и университетской экосистемы, как имманентной её части. Мировой опыт свидетельствует, что создание «с нуля» эффективных образовательных и научно-исследовательских комплексов на территориях - процесс очень сложный, требующий долгого времени и гарантированного стабильного финансирования. Не случайно, а закономерно верхние позиции авторитетных международных рейтингов занимают университеты с вековой, и более, историей: Кембриджский, Оксфордский, Стэндфордский, Гарвардский и др. И из отечественных университетов в первые сотни некоторых мировых рейтингов попадает только МГУ.

По отношению к размещению в городе можно различать, как минимум два типа университетов - автономные, или загородные, и городские. Большинство европейских относятся к типу городских университетов - это высшие учебные заведения, вовлечённые в социальные, экономические и культурные ресурсы городов, в которых они расположены. Именно поэтому это не просто университеты «в городе», а «городские» университеты. Городские университеты - это феномен, по преимуществу, Европы, некоторых крупных городов США, Китая и Юго-Восточной Азии.

Из почти 700 университетов США только около 60 являются городскими, все они, как правило, расположены в круп-

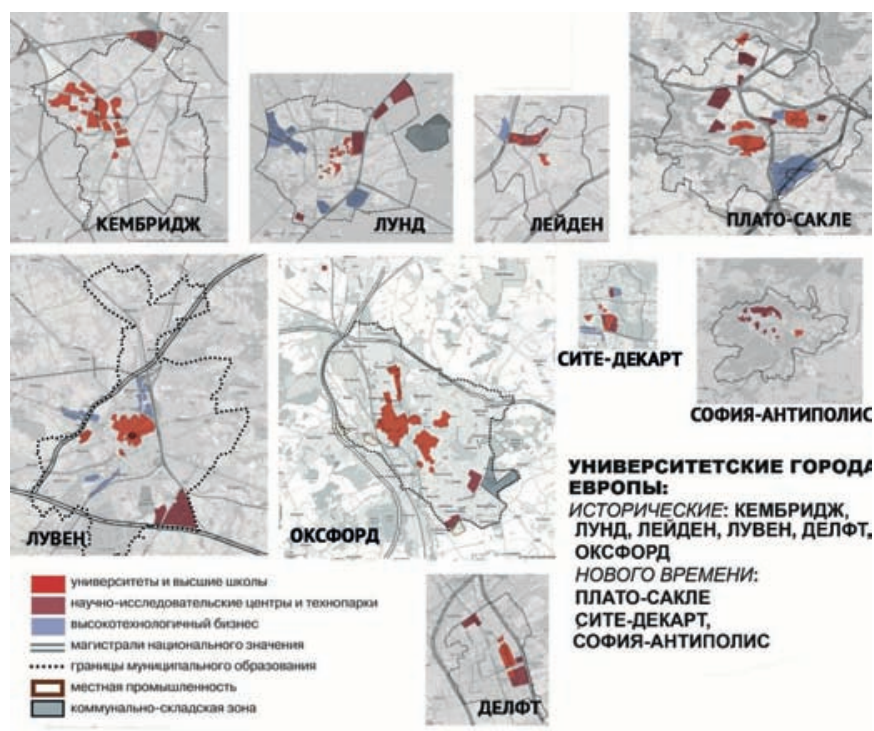

Рис. 3. Университетские города Европы - технополисы мирового уровня. Автор схемы Г.И. Кулешова нейших городах страны. Среди них университеты с мировой известностью - такие, например, как Бостонский университет, Массачусетский технический институт и Гарвард в Бостоне, университеты Остина, Питтсбурга, Далласа, Чикаго, НьюЙорка. Сами эти города относятся к инновационным центрам высшего порядка, что объясняется действием фактора Джейн Джекобс: «Инновации активнее возникают там, где много людей с разным опытом: инженеров, гуманитариев, учёных - которые обмениваются разными идеями» [11]. Другими словами, инновации не только развиваются разными и многими отраслями сразу, но и поддерживаются совокупностью всех знаний, как в естественных, так и в гуманитарных науках. Крупные города так же обеспечивают необходимую для эффективного развития инновационной сферы «критическую массу исследователей - своего рода питательный бульон для возникновения новых идей, технического и культурного обмена» [6].

Бостон как пример симбиоза города и университетов в обеспечении процветания экономики и формирования высокого качества городской среды

Университеты Бостона сыграли значительную роль в развитии такого феномена как «креативный класс» и «креативная среда»: именно благодаря своему креативному классу Бостон в течение как минимум пяти последних десятилетий признаётся одним из первых инновационных центров мира, здесь расположена самая «инновационная миля» в мире: на площади Кендалл (Kendall Square) в Кембридже самая высокая плотность IT- и биотехнологических компаний в мире на квадратную милю. Всего в научно-инновационном комплексе города занято в разные периоды от 700 до 800 тысяч специ-

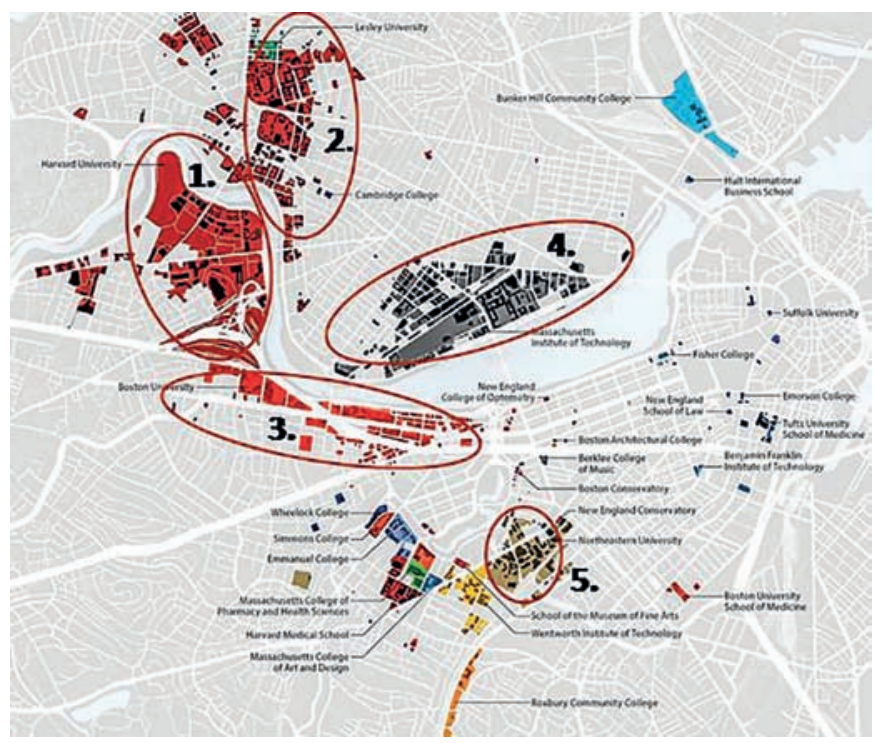

Puс. 4. Кампусы городских университетов на примере Бостона: 1 - Гарвардский, 2 - Кембриджский колледж, 3 Бостонский, 4 - Массачусетский технический институт, 5 - Северо-восточный Университет. Автор схемы Г.И. Кулешова, основа - карты Гугл 
алистов, в 122 университетах и колледжах обучается от 200 до 250 тысяч студентов. В прошлом веке, после периода расцвета в 50-70-е годы, экономика Бостона пережила серьёзное экономическое падение в 80-90-е годы, однако опора на мощный интеллектуальный потенциал якорных университетов (рис. 4) позволила Бостону уже на рубеже веков опять стать крупнейшим инновационным центром глобального масштаба в области биотехнологий. Бостон неоднократно занимал верхние позиции в различных версиях рейтингов качества жизни как американских, так и международных. По мнению авторитетного эксперта [12], он относится к категории «глобальных городов», обеспечивающих наилучшие условия для проживания и самореализации креативного класса, играющего роль приводного ремня экономики знаний.

Бостон - яркий пример города, модернизирующего городскую среду для привлечения представителей креативного класса, в администрации учреждён специальный департамент, отслеживающий количество работников $S \& \mathrm{E}^{1}$, привлечённых в город, особая забота направлена на математиков и сотрудников IT-сферы. Это обеспечивает реализацию STEMобразования ${ }^{2}$ как базовой опоры инновационной экономики - экономики знаний.

В области урбанистических инноваций Бостон ещё в начале 80-х годов предложил новые практики и методы работы с гражданским обществом, которые сейчас широко распространяются во всем мире. Именно здесь сам термин «урбанизация» стал пониматься не только как процесс формирования городского пространства и среды, но и как процесс роста самосознания самого городского сообщества жителей [10]

Самый наглядный пример - разработка и реализация первой в мире системы велодорожек в городе со сложившейся жесткой структурой территорий и транспортных магистралей. Этот проект реализовывался более двадцати лет - с начала 80-х годов, и на каждом этапе и фрагменте территории отрезок велосети был актом компромисса между велолюбителями, владельцами территорий и участков, жителями района и муниципальными властями.

Город известен проектом модернизации транспортной инфраструктуры [11], уникальным для американских городов, где такие крупные проекты являются исключительной редкостью. Важнейшей частью проекта было полное переформатирование фрагмента транспортных магистралей в плотной застройке города с освобождением 10 га площадей для новых бульваров и скверов. Проекты модернизации Бостона - это именно полное преобразование функционального назначения территориальных ареалов и зон на основе новых социальных, градостроительных, инфраструктурных технологий [12]. Повышающим фактором в этом процессе является четко выраженная социальная направленность проектов, обеспечивающая рост конкурентоспособности города.

Характерные особенности пространственной организации университетских кампусов англоязычного мира

Необходимо признать, что в большинстве случаев в США и англоязычных странах наблюдается автономное размещение университетских кампусов в сельской местности и маленьких городах, эта традиция ведёт своё начало от университетов Кембриджа и Оксфорда [10], первоначально расположенных в сельской пасторальной местности. Значение качества среды университетского кампуса невозможно переоценить: занятиям наукой и образованием свойственно некоторое функциональное уединение, созерцательность, необходимость сосредоточиться на предмете исследований, чему способствует природное окружение: «свобода науки и преподавания, а также охранение их от мирской суеты и светских соблазнов - таковы основы сложившейся традиции, стремящейся изолировать университетскую общину от остальных граждан и университетскую территорию от остального города» [16].

Тем не менее и городские, и «сельские» кампусы в США имеют ряд характерных черт, универсальных для формирования уникальности университетской среды ${ }^{3}$, которые в сумме можно обозначить как модель пространственно-планировочной организации кампуса. Эта модель характерна для англоязычного мира, однако её обаяния не избежали высокоразвитые страны Юго-Восточной Азии - Сингапур, Южная Корея.

1. Духовный центр - ОСь MИРA (AXIS MUNDI). Она символизирует знания, которые ждут открытия, направлена на поиск правды, гармонии, мира и согласия с природой; это сердце кампуса, как правило, пространство вокруг самого старого исторического корпуса, оно остаётся неизменным, незастроенным.

2. Иерархия пространств: 1 тип - грандиозное пространство, представляющее лицо университета; 2 тип - пространства университетских сообществ, учебных, функциональных или корпоративных групп; 3 - индивидуальные пространства студентов и преподавателей; в целом, невысокая плотность застройки, существенный процент свободных озеленённых пространств;

3. Полифункциональность территорий университета, выраженная в чересполосице расположения зданий разного функционального назначения, что создаёт смешанное использование по временным потокам, это обеспечивает отсутствие небезопасных зон запустения и обезлюженности территорий.

4. Обеспечение возможности развития исследовательской зоны университета, поскольку в современном университете исследования - одна из основ экономического процветания и независимости учреждения.

\footnotetext{
${ }^{1} \mathrm{~S} \& \mathrm{E}$ - соответствует российским ученым и инженерам

2 STEM: Science - Наука, Technology - Технология, Engineering - Инженерное дело, Маth - Математика. Образовательная система, направленная на междисциплинарный и проектный подход, в основе которого интеграция естественных наук, технологии, инженерного творчества на базе математики.

${ }^{3}$ Сформулированы в процессе консультирования дипломного проекта Е.П. Петровой «Кампус Технологического университета в 0бнинске», МАРХИ, 2016.
} 
5. Знаковые здания - один из приёмов создания яркой университетской среды: уникальные здания, идентифицирующие кампус как в контрасте со зданиями основной ткани кампуса, так и в городской среде; это, как правило, не более $10-15 \%$ от всех зданий.

6. Территории для рекреации и спорта, которые имеют очень большое значение в жизни студенческой общины, располагаются дискретно в нескольких местах кампуса, в непосредственной близости от жилых корпусов.

7. Основа функциональных связей на территории кампуса - пешеходные связи, благоустроенные и образующие плотную удобно спланированную сеть.

8. Велосипед - предпочтительный вид транспорта на территории кампуса. Для обеспечения эффективного пользования велосетью предусмотрены велопарковки около всех корпусов, учебных и других зданий, сервисные центры обслуживания, прокатная сеть.

9. Безопасность, как показал мировой опыт, практически не достигается возведением ограждений и прочими подобными мерами, здесь срабатывают такие стратегии, как камеры, плотность и полифункциональность застройки, планировочные меры по организации хорошо просматриваемых пространств, исключения тупиков и пр.

10. Артикулированность центра и границ кампуса.

11. Единство и разнообразие архитектурной стилистики - две равноправные стратегии развития университетской среды при учете особенностей сложившейся окружающей городской застройки.

В качестве примера практически идеальной модели воплощения перечисленных характеристик архитектурнопространственной организации можно привести кампус Техасского университета (далее ТУ) в Остине (столица штата Техас, около 1,0 млн жителей), публичного университета штата, относящегося к типу городских университетов. Университет входит в первую десятку Америки по количеству обучающихся студентов - больше 50000 студентов и 16500 преподавателей и служащих, это второй по величине работодатель в городе. Кампус ТУ занимает 350 га в центральной части города.

Университет был основан в 1883 году, и главное историческое здание расположено всего в километре от здания Конгресса штата (рис. 5, 6, 7). На территории университета находятся семь музеев и семнадцать библиотек, в том числе Президентская Линдона Джонсона, а также специализированные структуры, включая Обсерваторию. Музей искусств - самый большой университетский музей искусств в Америке (14,0 тыс. кв. м, 17000 произведений из Европы, Соединённых Штатов и Латинской Америки), университетский стадион, получивший название Техасского, один их самых больших в стране. Таким образом, Техасский университет является, по существу, культурным центром столицы Техаса.

\footnotetext{
${ }^{4}$ Все иллюстрации в статье, кроме особо оговоренных, взяты из открытого доступа сети Интернет.
}

Сорок общежитий университетского кампуса рассчитаны на проживание 7100 студентов. Наибольшее общежитие на 3200 человек, состоящее из двух башен 14 и 10 этажей, - одно из немногих многоэтажных студенческих общежитий в Америке. Однако абсолютное большинство студентов проживают в частных общежитиях, жилищных кооперативах, квартирах, или в общественных коммунах и других местах жительства вне университетского городка. Это характерная ситуация для западных университетов в целом, где она воспринимается как норма.

Обращает внимание развитость и значительная доля так называемой мягкой инфраструктуры - концертные залы и площадки, музеи, библиотеки, спортивные сооружения, которые в равной степени являются достоянием как университета, так и города, (рис. 8). Это и есть пример открытости

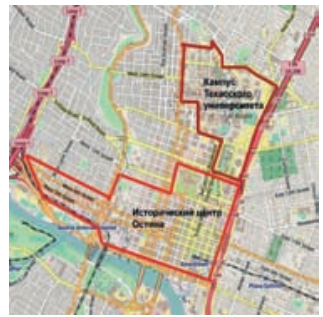

Рис. 5. Размещение кампуса ТУ в Остине

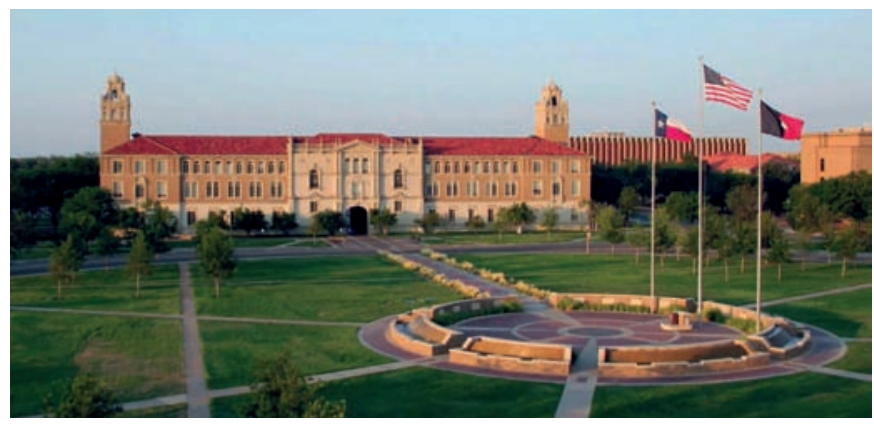

PUс. 7. Центральная эспланада - AXIS MUNDI Университета

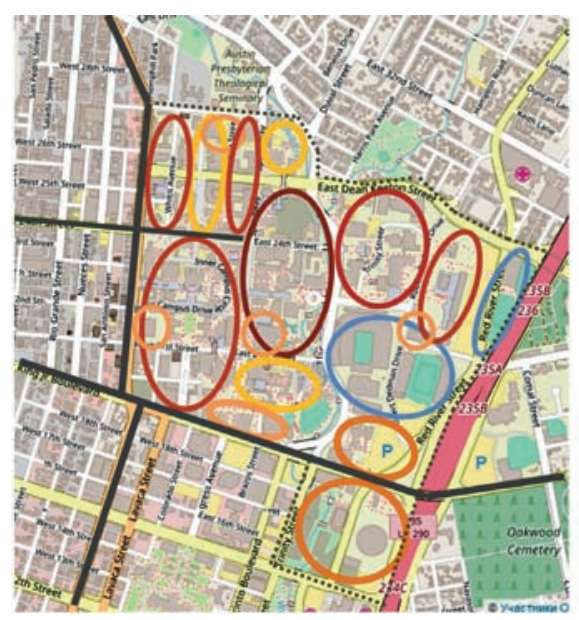

ТЕХАССКИЙ УНИВЕРСИТЕТ, ОСТИН ФУНКЦИОНАЛЬНАЯ СХЕМА KAMחYC -350 ra

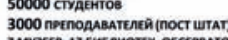

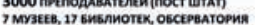

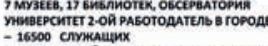

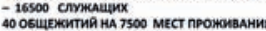

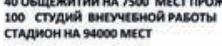

Рис. 8. Функциональная схема Техасского университета в Остине. Автор схемы Г.И. Кулешова, основа - карты Гугл 
и симбиоза, когда Университет признан центром культурной жизни и фактором социальных преобразований в городе.

Столица Техаса - один из самых растущих городов страны за счет высококвалифицированных мигрантов, привлекаемых созданной средой, культурная столица всего юга США, известен большим количеством культурных событий, особенно музыкальных фестивалей, в организации и проведении которых Университет играет главную роль. Благодаря этому официальный слоган Остина - «Всемирная столица музыки».

Таким образом, очевидно, что исторически сложившиеся и тщательно поддерживаемые традиции пространственной организации кампусов позволяют западным университетам иметь запоминающийся, выразительный и уникальный образ, основанный на оригинальной архитектуре и органичной планировке, в которых отражены преемственность традиций, национальные особенности, дух времени и места. Эти обстоятельства имеют неоценимое значение для формирования корпоративной культуры университета и индивидуальных личностных качеств обучающихся, а также превращают университетский кампус в существенный фактор городской жизни, обеспечивающий конкурентоспособность города на мировых рынках.

Представляется, что именно указанные выше характеристики имеются в виду в декларации [1] о создании в России университетских кампусов мирового уровня. На это указывает и пример из новейшей истории, на который ссылаются авторы

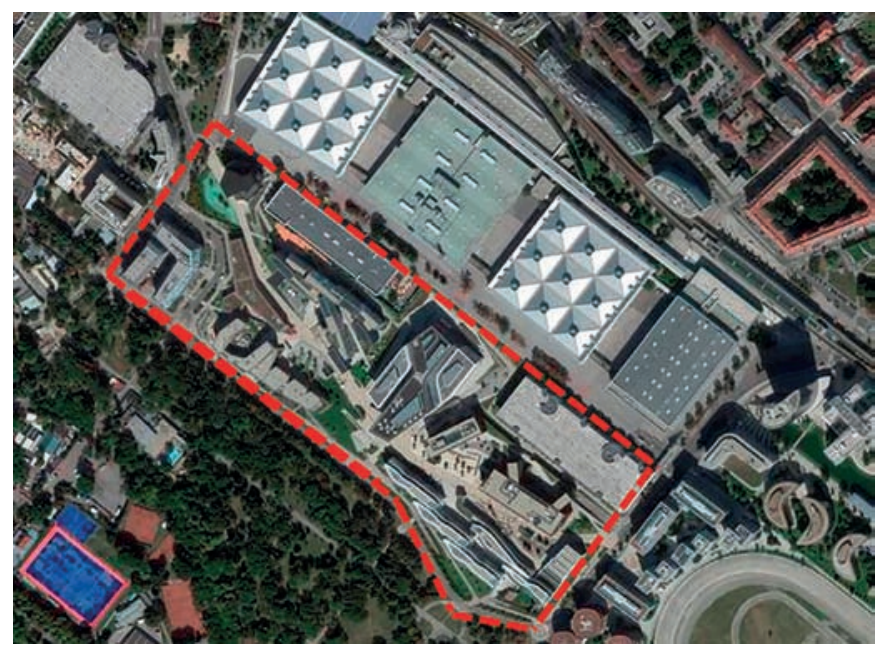

Рис. 9. Размещение кампуса Вэу доклада - «Кампус Венского экономического университета», который реализован по принципу «город в городе» [1].

Венский экономический университет входит в Топ-10 мировых школ экономики и бизнеса, что позволило обеспечить беспримерные объёмы финансирования и привлечь к проектированию лучших мировых архитекторов (например, Заха Хадид - одна из них).

Важным для темы «университет-город» является то обстоятельство, что новый кампус разместили вблизи исторического центра Вены, центральных территорий, мест расположения других венских университетов, большого объединенного студенческого спортивного комплекса со стадионом (рис. 9). Сейчас кампус ВЭУ является украшением и новой достопримечательностью города.

Идеология нового кампуса ВЭУ - «Университет будущего: интернациональность, инновации, разнообразие». В новом кампусе ВУ современная университетская концепция выливается в пространственную форму, а архитектурно-планировочные приёмы отражают принципы инновационной организации Университета - «город в городе». В центре планировочной композиции внушительный библиотечно-образовательный центр (Library \& Learning Center) архитектора Захи Хадид (рис. 10). Вокруг него группируются комплексы зданий с лекционными залами, администрация, научно-исследовательские департаменты (рис. 11). Весь университетский городок построен на основе концепции зелёного строительства (Green Building). Не только сами здания,

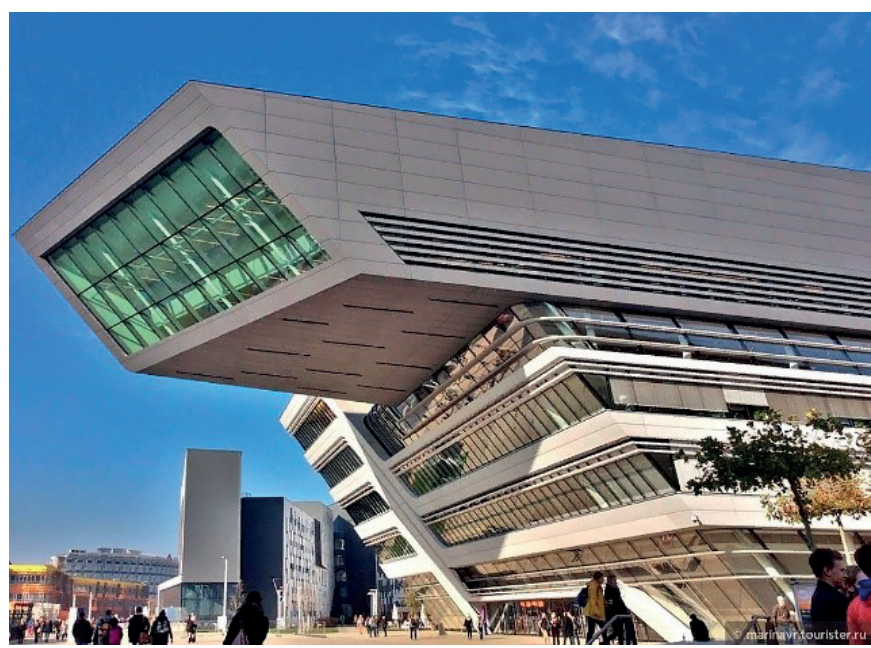

Puс. 10. Главный корпус кампуса библиотечно-образовательный центр (Library \& Learning Center - LC). Архитектор Заха Хадид

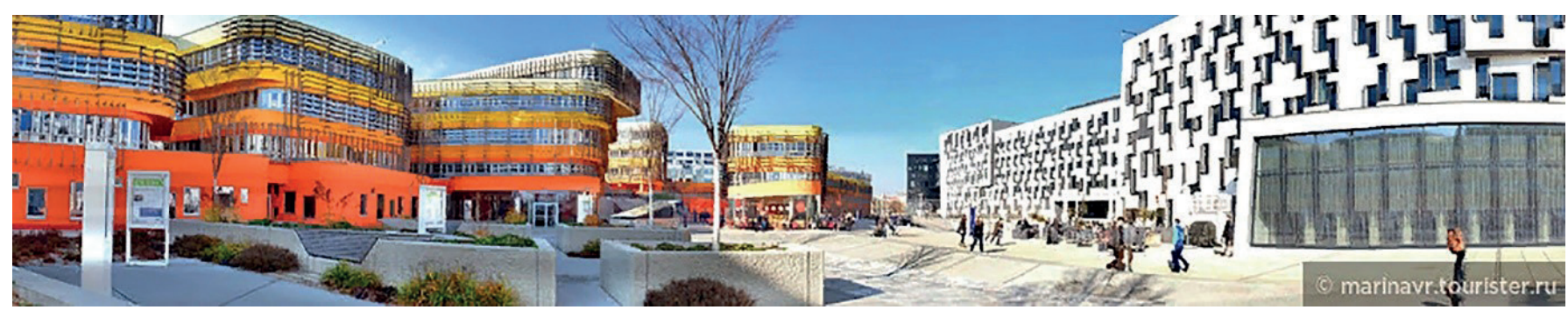

Pис. 11. Корпуса учебного, научно-исследовательского и офисного назначения вдоль основного центрального пространства кампуса 
но и просторные площади между ними предлагают множество возможностей для коммуникаций разного уровня и назначения; 55000 из 100000 квадратных метров общей полезной площади открыты как для обитателей кампуса, так и для публики. Заборы и ограждения противоречат концепции открытого кампуса.

В кампусе ВЭУ могут работать, учиться, исследовать и преподавать 25000 студентов и 1500 сотрудников. В дополнение к классическим университетским областям, таким как учебные помещения, библиотеки, офисные помещения, в кампусе есть различные общедоступные объекты: гастрономия, пекарня, супермаркет, книжные магазины, детский сад и спортивный центр. Все это работает не только для кампуса, но и для города. К 2025 году кампус должен быть сформирован как популярная научная/коммуникационная точка не только городского, но и европейского значения.

Кампусы университетов городского типа как американских, так и европейских, можно разделить на две группы: локальные и дисперсные. Если в США безусловно преобладает локальный тип кампуса, то в Европе в значительном количестве университетов можно наблюдать дисперсный тип. В частности, кампусы Женевского университета и университета Лодзи , которые показаны в [1] в качестве примеров для создания кампусов, в территориально-планировочном отношении представляют именно дисперсный тип.

Пример подлинно современного многоаспектного развития университетского кампуса дисперсного типа даёт Университет Утрехта (рис. 12, 13, 14) (1636 год основания, 30000 студентов, в первой сотне трёх основных мировых рейтингов по разным образовательным программам), чётко улавливающий основные тенденции в этом процессе и следующий им в своей стратегии [17]. Утрехтский университет планирует инвестировать более 800 млн евро в строительство и реконструкцию в течение следующих десяти лет, отвечая на вызовы изменений в образовании и исследованиях, предъявляющих новые требования к недвижимости: портфель недвижимости будет сокращён, модернизирован и сосредоточен в центре города и в научном парке Утрехта.

Президент Исполнительного совета Университета Утрехта так комментирует стратегию развития: «Возможностей для цифрового образования становится всё больше, а исследования и образование становятся всё более междисциплинарными. Нам нужны гибкие условия, которые облегчают эти изменения и поощряют создание сообществ. Поэтому

${ }^{5}$ Причины, обуславливающие необходимость подражания кампусам Женевского университета и университета Лодзи, как таковые остались недоступны для понимания, но Женевский хотя бы занимает 144 место в рейтинге THE 2020. Университет Лодзи - только шестой в рейтинге университетов Польши, а достоверные данные о его международном авторитете отсутствуют. Обычно об этом свидетельствует количество иностранных студентов, но в Университете Лодзи оно менее 4\%, в настоящее время эта цифра уступает многим российским университетам. Состояние учебных корпусов, качество студенческих общежитий университета Лодзи и общее состояние городской среды, по свидетельствам очевидцев (https://www. ucheba.ru/article/211, https://isttravel.ru/index.pl?act= PRODUCT\&id=224) также оставляет желать лучшего. мы должны более эффективно использовать имеющееся у нас пространство. Мы намерены иметь меньше квадратных метров и использовать их более эффективно, например, для совместного использования рабочих мест. Здесь есть место для гибкости, поскольку в настоящее время мы не используем наши квадратные метры оптимально» [17].

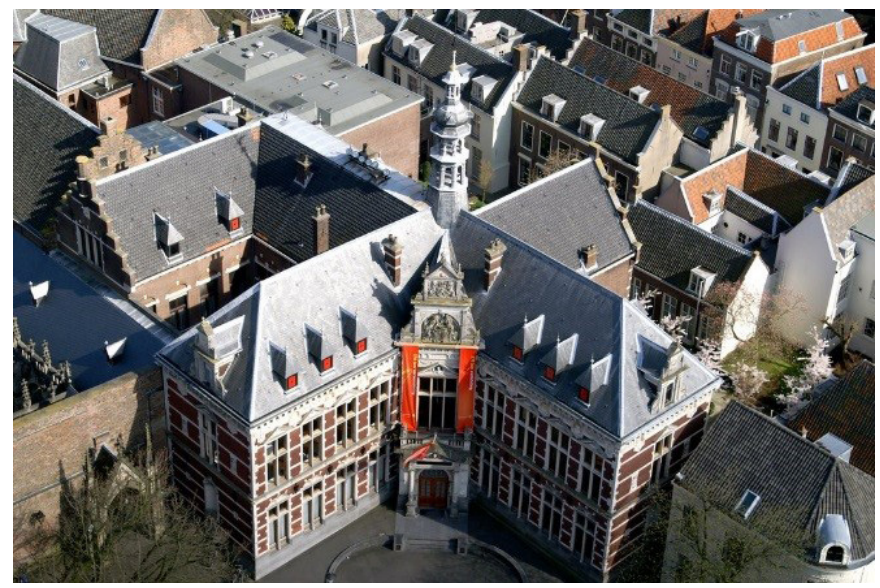

Рис. 12. Исторический корпус Университета

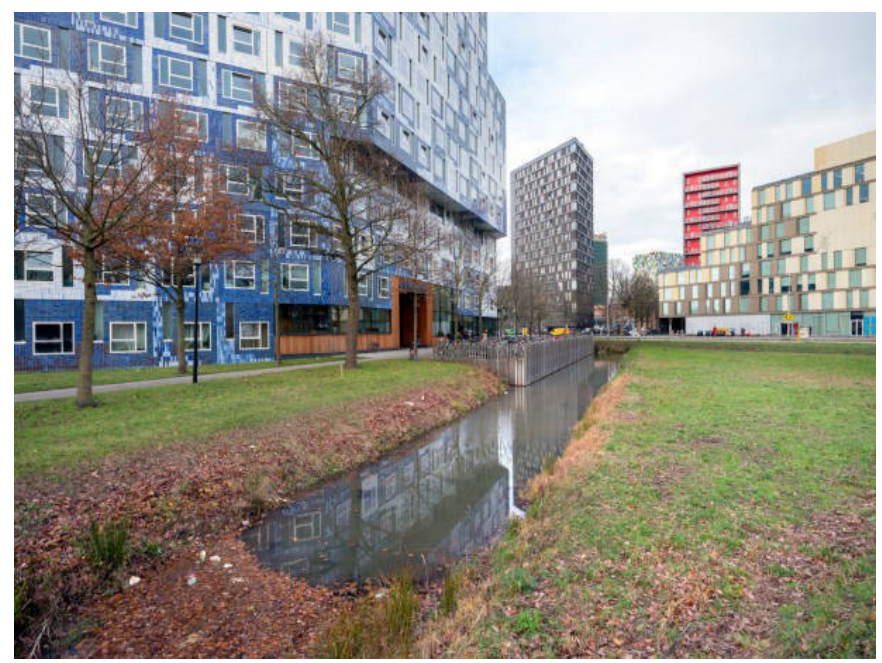

Рис. 13. Университетский кампус в Научном парке Утрехта

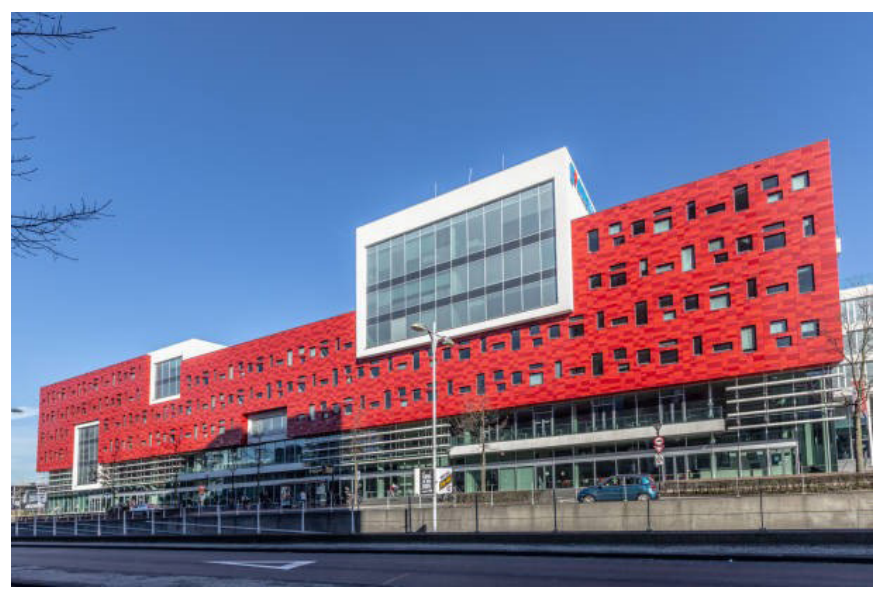

Pис. 14. Учебно-лабораторный корпус Университета в Научном парке Утрехта 
В связи с проникновением цифровых технологий в образование, в том числе обучения онлайн, Университет считает возможным сократить потребность в площадях на $30 \%$, отдавая предпочтение кооперированным формам использования недвижимости.

Особенно важными, с нашей точки зрения, являются следующие позиции в стратегии развития: 1) университет останется в центре города; 2) объекты в центре города должны быть консолидированы территориально; 3) несмотря на то, что земля в центре города на 25\% дороже, чем в Научном парке Утрехта, Университет сохранит профиль в городе. Связь с историческим Утрехтом важна для университета: университетские праздники проходят в центре города по сценариям, которые не менялись с XVIII века, что позволяет студентам ощутить причастность как к многовековым академическим традициям, так и к истории Утрехта.

В последние годы в центре Утрехта создан настоящий университетский квартал (Universiteitskwartier), где расположены гуманитарный факультет и факультет права, экономики и управления. Центральный корпус Утрехтского университета, в сердце центра города - это старинное средневековое здание в готическом стиле с просторными лекционными залами, большой библиотекой и многочисленными аудиториями.

Международный кампус Утрехта (ICU), расположенный на месте бывших военных казарм Кромхаута, - идеальное место для кампуса, где легко сочетаются проживание, образование и культура. Это закрытая территория с красивыми зданиями (некоторые из них являются городскими памятниками архитектуры), которые идеально подходят как для проживания, так и для обучения, здесь много зелёных насаждений и пешеходных троп. Научный парк Утрехта, расположенный на востоке города, является периферийным по расположению, но отнюдь не окраинным кампусом Утрехтского университета. Научный парк Утрехта занимает площадь более 300 гектаров, из которых 260 принадлежат университету. Университетский городок включает учебные комплексы, общежития для студентов, библиотеки, лаборатории, исследовательские центры, а также развлекательные объекты и тренажерные залы, - всё необходимое для учёбы и отдыха.

\section{Заключение}

Университеты в большинстве стран запада выступают системообразующими факторами креативной городской среды, формирующейся «мягкой инфраструктуры», элементы которой обеспечивают максимальное разнообразие форм социальной, культурной жизни, условий сервисного, рекреационного и культурного обслуживания.

Города в Европе имеют более чем тысячелетний опыт сосуществования с университетами, некоторые из этих городов являют собой полный симбиоз со своим университетом (Кембридж, Оксфорд). Университет - важнейший фактор истории, экономики и культуры такого города, в общественных представлениях они практически тождественны. При этом, и некоторые университеты новейшей послевоенной истории организовали вокруг себя города (София-Антиполис, Плато (окле), поднявшись на этой основе до научно-инновационных центров мирового класса - технополисов.

Мировой опыт свидетельствует, что создание «с нуля» эффективных образовательных и научно-исследовательских комплексов на территориях - процесс очень сложный, требующий долгого времени и гарантированного стабильного финансирования.

По отношению к размещению в городе можно различать, как минимум два типа университетских кампусов - автономные, или загородные, и городские. Большинство европейских относятся к типу городских университетов - это высшие учебные заведения, вовлеченные в социальные, экономические и культурные ресурсы городов, в которых они расположены. Именно поэтому это не просто университеты «в городе», а «городские» университеты. Городские университеты - это феномен, по преимуществу, Европы, некоторых крупных городов США и других англоязычных стран, Китая и Юго-Восточной Азии.

Размещение университетов в крупных городах, причём в непосредственной близости от исторического центра, целесообразно и оправданно, поскольку крупные города обеспечивают необходимую для эффективного развития инновационной сферы критическую массу исследователей - своего рода питательный бульон для возникновения новых идей, технического и культурного обмена.

В инновационной экономике университетам принадлежит ключевая роль в обеспечении инновационного развития, подготовке необходимых ключевых компетенций для достижения технологического рывка.

Для реализации программы создания межуниверситетских кампусов в российских городах с существующей опорной базой высшего образования целесообразно использовать имеющийся зарубежный опыт в разумных рамках экономических реалий страны при обеспечении эффективного функционирования образовательного комплекса города и его роли в повышении качества жизни и инвестиционной привлекательности территории.

\section{Лuтература}

1. Дмитрий Чернышенко и Валерий Фальков провели стратегическую сессию по созданию университетских кампусов мирового уровня [Электронный ресурс] // Министерство науки и высшего образования. Официальный сайт. - Режим доступа: https://minobrnauki.gov.ru/press-center/ news/?ELEMENT_ID=34815 (дата обращения 16.11.2021)

2. Создание нового образовательного пространства в рамках Федерального проекта «Экспорт образования» Национального проекта «0бразование» : Буклет. - М. : Агентский блок ГКР ВЭБ РФ, 2019.

3. Модель для сборки университетов 4.0, или Для кого не наступит будущее. Что делать вузам, чтобы выжить в меняющемся мире [Электронный ресурс] / INDICATOR.RU 
[сайт]. - Режим доступа: https://indicator.ru/engineeringscience/konferenciya-5-100-universitety.htm (датаобращения 19.11.2021)

4. Кулешова, Г.И. Градостроительное обеспечение университетских кампусов в инновационной экономике (на примерах Томска и Уфы) // Теоретические основы градостроительства : Сборник статей /Х Владимировские чтения; Российская академия архитектуры и строительных наук, Самарский государственный технический университет. 2020. - Самара :СамГАСУ, 2020. - C. 70-85 D0I: 10.17673/ RAACS.2020.1.8 русс. англ

5. Лободанова, Д.Л. Комфортность среды как фактор инновационного развития города / Д.Л. Лободанова, И. Самсон, К. Курле; под ред. Д.Л. Лободановой. - М. : Издательский дом «Дело», 2013. - 180 с.

6. Кулешова, Г.И. Территории инноваций: технопарки технополисы - регионы науки / Г.И. Кулешова. - М. : Научный мир, 2019. - 368 с

7. Флорида, Р. Креативные класс: люди, которые меняют будущее / ЗР. Флорида. - М. : Классика-XXI, 2007. - 421 с

8. Канелла, Г. Прошлое и будущее университетского «антигорода» / Г. Канелла // Современная архитектура. 1973. -№ 2.

9. University of 0xford // Academic Positions. - Режим доступа: http://academicpositions.eu/employer/universityof-oxford/ (дата обращения 06.11.2021).

10. Душкина, Н.О. Формирование архитектурной среды в университетских городах Великобритании (Оксфорд и Кембридж). Автореферат дисертации. - М. : МАРХИ, 1982. - 149 с.

11. Джекобс, Дж. Города и богатство наций: принципы экономической жизни / под ред. канд. экон. наук 0.Н. Лугового. Пер. с англ. Д.А. Ананьев. - Новосибирск : Культурное наследие, 2009. - 243 с.

12. 3 Глобальные города: постиндустриальные производственные площадки [Электронный ресурс] / Саския Сассен // Прогнозис. - 2005. - № 4. // Urban Sociology. - Режим доступа: http://les-urbanistes.blogspot.com/2009/01/blogpost.htm (дата обращения 08.09.2021). Русс.

13. Василий Гнедовский. Современные проблемы развития постиндустриального общества в городах США и Европы [Электронный ресурс] // «Русский архипелаг». Сетевой проект «Русского мира». Режим доступа: https://buk.irk.ru/ exp_seminar/4/doc4.pdf (дата обращения 10.12.2021)

14. Boston Big Dig, Central Artery / Tunnel Project, Massachusetts [Электронный ресурс] // Сайт Road Traffic technology. - Режим доступа: http://www.roadtraffictechnology.com/projects/big_dig/ (дата обращения 08.12.2021).

15. Кулешова, Г.И. Экологизация городской среды: стандарты и направления структурных преобразований / Г.И. Кулешова, К.И. Сергеев. // Социальные стандарты качества жизни в архитектуре, градостроительстве и строительстве : Сборник трудов РААСН. -Москва-Орел: Юго-Зап. Гос. Университет, 2011. - С. 85-91. русс
16. Кулешова Г.И. Образы науки и архитектура научных комплексов / Г.И. Кулешова // Вопросы философии. -1992. - № 4

17. Утрехтский университет инвестирует в объекты будущего/ Официальный сайт Университета Утрехта [Электронный ресурс] // Utrecht University. - Режим доступа: https://www. uu.nl/en/news/utrecht-university-to-invest-in-facilities-ofthe-future (дата обращения 15.11.2021).

\section{References}

1. Dmitrii Chernyshenko i Valerii Fal'kov proveli strategicheskuyu sessiyu po sozdaniyu universitetskikh kampusov mirovogo urovnya [Dmitry Chernyshenko and Valery Falkov held a strategic session on the creation of worldclass university campuses]. Ministerstvo nauki $i$ vysshego obrazovaniya. Ofitsial'nyi sait [Ministry of Science and Higher Education. Official site]. Access mode:https://minobrnauki. gov.ru/press-center/news/?ELEMENT_ID=34815 (Accessed 11/16/2021) (In Russ.)

2. Sozdanie novogo obrazovatel'nogo prostranstva $v$ ramkakh Federal'nogo proekta «Eksport obrazovaniya» Natsional'nogo proekta «Obrazovanie» [Creation of a new educational space within the framework of the Federal Project "Export of Education" of the National Project "Education"]. BookletBuklet. Moscow, Agentskii blok GKR VEB RF Publ., 2019. (In Russ.)

3. Model' dlya sborki universitetov 4.0, ili Dlya kogo ne nastupit budushchee. Chto delat' vuzam, chtoby vyzhit' v menyayushchemsya mire [Model for the assembly of universities 4.0, or For whom the future does not come. What universities should do to survive in a changing world]. INDICATOR.RU [site Access mode: https://indicator.ru/engineering-science/ konferenciya-5-100-universitety.htm (Accessed 19.11.2021). (In Russ.)

4. Kuleshova G.I. Gradostroitel'noe obespechenie universitetskikh kampusov $v$ innovatsionnoi ekonomike (na primerakh Tomska i Ufy) [Urban planning support of university campuses in an innovative economy (on the examples of Tomsk and Ufa)]. In: Teoreticheskie osnovy gradostroitel'stva : Sbornik statei, X Vladimirovskie chteniya; Rossiiskaya akademiya arkhitektury $i$ stroitel'nykh nauk, Samarskii gosudarstvennyi tekhnicheskii universitet. 2020 [Theoretical foundations of urban planning: Collection of articles / X Vladimirovskie readings; Russian Academy of Architecture and Construction Sciences, Samara State Technical University. 2020]. Samara, SamGASU Publ., 2020, pp. 70-85. DOI: 10.17673/RAACS.2020.1.8 (In Russ., abstr. in Engl.)

5. Lobodanova D.L., Samson I., Kurle K. Komfortnost' sredy kak faktor innovatsionnogo razvitiya goroda [Comfort of the environment as a factor of innovative development of the city], D.L. Lobodanova (ed.). Moscow : Publishing house "Delo", 2013,180 p. (In Russ.)

6. Kuleshova G.I. Territorii innovatsii: tekhnoparki - 
tekhnopolisy - regiony nauki [Territories of innovations: technoparks - technopolises - regions of science]. Moscow, Nauchnyi mir Publ., 2019, 368 p. (In Russ.)

7. Florida, R. Kreativnye klass: lyudi, kotorye menyayut budushchee [Creative class: people who change the future]. Moscow, Klassika-XXI Publ., 2007, 421 p. (In Russ.)

8. Kanella, G. Proshloe i budushchee universitetskogo «antigoroda» [Past and future of the university "anti-city"]. In: Sovremennaya arkhitektura [Modern architecture], 1973, no. 2. (In Russ.)

9. University of 0xford. Academic Positions. Access mode: http://academicpositions.eu/employer/university-of-oxford/ (Accessed 11/06/2021). (In Engl.)

10. Dushkina, N.0. Formirovanie arkhitekturnoi sredy $v$ universitetskikh gorodakh Velikobritanii (Oksford i Kembridzh) [Formation of the architectural environment in the university cities of Great Britain (0xford and Cambridge).]. Abstract of dissertation. Moscow, MARKhI, 1982, 149 p.

11. Dzhekobs, Dzh. Goroda i bogatstvo natsii: printsipy ekonomicheskoi zhizni [Cities and wealth of nations: principles of economiclife ], 0.N. Lugovoi (ed.), trans. from Engl. D.A. Anan'ev. Novosibirsk, Kul'turnoe nasledie Publ., 2009, 243 p.

12. Sassen, S. Global'nye goroda: postindustrial'nye proizvodstvennye ploshchadki [Modern problems of the development of post-industrial society in the cities of the United States and Europe Global cities: post-industrial production sites]. In: Prognozis, 2005, no. 4. Access mode: http://les-urbanistes.blogspot.com/2009/01/blog-post.htm (Accessed 08.09.2021). (In Russ.)

13. Vasilii Gnedovskii. Sovremennye problemy razvitiya postindustrial'nogo obshchestva $v$ gorodakh SShA i Evropy [Modern problems of the development of post-industrial society in the cities of the United States and Europe]. In:
«Russkii arkhipelag». Setevoi proekt «Russkogo mira» ["Russian Archipelago". Russian World network project]. Access mode: https://buk.irk.ru/exp_seminar/4/doc4.pdf (Accessed 10.12.2021) (In Russ.)

14. Boston Big Dig, Central Artery / Tunnel Project, Massachusetts [Elektronnyi resurs] // Sait Road Traffic technology. Access mode: http://www.roadtraffic-technology. com/projects/big_dig/ (Accessed 08.12.2021). (In Engl.)

15. Kuleshova G.I., Sergeev K.I. Ekologizatsiya gorodskoi sredy: standarty i napravleniya strukturnykh preobrazovanii [Greening the urban environment: standards and directions of structural transformations]. In: Sotsial'nye standarty kachestva zhizni $v$ arkhitekture, gradostroitel'stve $i$ stroitel'stve [Social standards of quality of life in architecture, urban planning and construction: Collection of works of]: Sbornik trudov RAASC]. Moscow-Orel, South-West. State University, 2011, 85-91 pp. (In Russ.)

16. Kuleshova G.I. Obrazy nauki i arkhitektura nauchnykh kompleksov [Images of science and architecture of scientific complexes]. In: Voprosy filosofii [Questions of Philosophy], 1992, no. 4. (In Russ.)

17. Utrekhtskii universitet investiruet v ob"ekty budushchego []/ Ofitsial'nyi sait Universiteta Utrekhta [Questions of Philosophy]. In: Utrecht University Site. Access mode: https:// www.uu.nl/en/news/utrecht-university-to-invest-in-facilitiesof-the-future (Accessed 15.11.2021). (In Engl.) 